Article

\title{
Preparation and photocatalytic activity of rutile $\mathrm{TiO}_{2}$ and goethite composite photocatalysts
}

\author{
XIE Weimiao a, CHEN Hui a, ZHANG Xuanhui a ${ }^{\text {a }}$ HU Xianchao ${ }^{\mathrm{c}}$, LI Guohua a,b,* \\ a School of Chemical Engineering and Materials Science, Zhejiang University of Technology, Hangzhou 310032, Zhejiang, China \\ b State Key Laboratory Breeding Base of Green Chemistry Synthesis Technology, Zhejiang University of Technology, Hangzhou 310032, Zhejiang, China \\ ${ }^{c}$ Research Center of Analysis and Measurement, Zhejiang University of Technology, Hangzhou 310032, Zhejiang, China
}

\section{A R T I C L E I N F O}

Article history:

Received 21 October 2012

Accepted 12 March 2013

Published 20 June 2013

\section{Keywords:}

Titanium dioxide

Goethite

Composite material

Photocatalytic activity

Methyl orange

\begin{abstract}
A B S T R A C T
Rutile $\mathrm{TiO}_{2}$ and goethite $(\alpha-\mathrm{FeOOH})$ composite photocatalysts were fabricated by hydrolysis and precipitation using titanium tetrachloride as a precursor and $\alpha$ - $\mathrm{FeOH}$ as a support. The samples were characterized by X-ray diffraction, scanning electron microscopy, transmission electron microscopy, energy-dispersive X-ray spectroscopy, and X-ray photoelectron spectroscopy. The results show that at lower temperature, rutile $\mathrm{TiO}_{2}$ particles coat on the surface of $\alpha$-FeOOH particles to form rutile $\mathrm{TiO}_{2}-\alpha-\mathrm{FeOOH}$ composite photocatalyst. At higher temperature, iron ions are doped into the rutile $\mathrm{TiO}_{2}$ lattice to form iron-doped rutile $\mathrm{TiO}_{2}$ tubes; at medium temperature, the sample is a mixture with both composite and iron-doped structures. The photocatalytic activity of the samples is estimated by their ability to degrade methyl orange under irradiation with ultraviolet-visible light (200-800 nm) at ambient temperature. The photocatalytic activities of the samples are improved compared with that of pure rutile $\mathrm{TiO}_{2}$ and $\alpha-\mathrm{FeOOH}$. The sample containing a mixture of composite and iron-doped structures shows the highest photocatalytic activity of that investigated. As a result, the photocatalytic activity of $\mathrm{Ti}_{2} \mathrm{O}$ could be improved effectively by combining with $\alpha-\mathrm{FeOOH}$ or doping iron.
\end{abstract}

(c) 2013, Dalian Institute of Chemical Physics, Chinese Academy of Sciences. Published by Elsevier B.V. All rights reserved.

\section{Introduction}

How to solve environmental issues is currently an important subject. During the next two decades, control of environmental pollution will become a global problem that urgently needs to be solved [1-3]. Use of semiconductor photocatalysts to treat environmental pollution is a promising solution to this problem [4-6]. Many semiconductor photocatalyst materials have been used for this purpose; among them, titanium dioxide $\left(\mathrm{TiO}_{2}\right)$ has received intense attention. It has been widely used to treat environmental pollution in water and air $[7,8]$ owing to its non-toxic and exhibits high photochemical stability, high catalytic efficiency, and strong oxidative ability without secondary pollution.

However, $\mathrm{TiO}_{2}$ semiconductor photocatalysts possess some obvious disadvantages. First, the band gap of $\mathrm{TiO}_{2}$ is wide (that of anatase is up to $3.2 \mathrm{eV}$ ), corresponding to an absorption threshold of $387.5 \mathrm{~nm}$. This means it only absorbs ultraviolet (UV) light, so it has almost no response to visible light, and can only use approximately 3\%-5\% of sunlight. Second, the lifetime of photoinduced charge carriers in $\mathrm{TiO}_{2}$ is very short, ranging from nanoseconds to picoseconds, and their recombination

\footnotetext{
*Corresponding author. Tel: +86-571-88320418; Fax:+86-571-88320544; E-mail: nanozjut@zjut.edu.cn

This work was supported by the National Natural Science Foundation of China (21173193), the Natural Science Foundation of Zhejiang Province (Y4080209, Y406094), the Innovative Demonstration Base for Postgraduate Education of Zhejiang Chemical Engineering and New Material (2004), and the Key Scientific Innovation Group for the Synthesis Technology of Green Chemistry of Zhejiang Province (G1201101001601/001).
} DOI: 10.1016/S1872-2067(12)60569-5 | http://www.sciencedirect.com/science/journal/18722067 | Chin. J. Catal., Vol. 34, No. 6, June 2013 
rate is high. These shortcomings limit the photocatalytic efficiency of $\mathrm{TiO}_{2}$. Therefore, how to improve the photocatalytic efficiency of $\mathrm{TiO}_{2}$ photocatalysts are important to realize its practical application.

The band gap of $\mathrm{TiO}_{2}$ photocatalyst can be narrowed and its recombination rate of photoinduced charge carriers can be reduced by controlling its crystal structure and surface physicochemical properties [9]. Such control can be achieved by doping $\mathrm{TiO}_{2}$ with transition metal ions [10-12] such as $\mathrm{Fe}^{3+}$, $\mathrm{Cr}^{3+}, \mathrm{Mn}^{2+}$, and $\mathrm{Co}^{2+}$ with full or half-full electronic configuration or non-metallic elements such as N, S, F, and V [13-15], or by combining $\mathrm{TiO}_{2}$ with a semiconductor with a narrow band gap. In recent years, multiphase composite systems including $\mathrm{Fe}_{2} \mathrm{O}_{3} / \mathrm{TiO}_{2}$ [16], $\mathrm{TiO}_{2} / \mathrm{SiO}_{2}$ [17], $\mathrm{TiO}_{2} / \mathrm{WO}_{3}$ [18], and $\mathrm{TiO}_{2} / \mathrm{ZnO}$ [19] have been widely investigated. The semiconductor material $\alpha-\mathrm{FeOOH}$ is used as a support for $\mathrm{TiO}_{2}$ because of its narrow band gap ( $2.6 \mathrm{eV}$ ). Combining $\mathrm{TiO}_{2}$ with $\alpha-\mathrm{FeOOH}$ can reduce its band gap and extend its light response to the visible range $[20,21]$. In addition, $\alpha-\mathrm{FeOOH}$ can provide $\mathrm{Fe}^{3+}$ for metal ion doping, and improve the performance of $\mathrm{TiO}_{2}$ photocatalysts.

$\mathrm{TiO}_{2} / \alpha-\mathrm{FeOOH}$ composite photocatalysts have been investigated extensively. Liang et al. [20] fabricated a $\mathrm{TiO}_{2} / \mathrm{FeOOH}$ composite photocatalyst with core-shell structure by hydrolysis and precipitation and noted an obvious synergistic effect between titania and $\alpha-\mathrm{FeOOH}$. In addition, its ability to photocatalytically degrade organic compounds was improved. Rawal et al. [21] found that a $\mathrm{TiO}_{2} / \mathrm{FeOOH}$ nanocomposite material degraded gaseous 2-propanol into $\mathrm{CO}_{2}$ under irradiation with visible light $(\lambda \geq 420 \mathrm{~nm})$, and its degradation efficiency was higher than that of $\mathrm{TiO}_{2}$ alone. However, current reports rarely consider the relationships between preparation conditions, microstructure and performance of $\mathrm{TiO}_{2} / \alpha-\mathrm{FeOOH}$ photocatalysts. Here, we report a novel approach to fabricate composite and doped $\mathrm{TiO}_{2} / \alpha-\mathrm{FeOOH}$ photocatalysts. The effect of preparation conditions on photocatalytically degrade methyl orange is investigated. In addition, the correlation between the photocatalytic performance of the photocatalyst and its microstructure is assessed.

\section{Experimental}

\subsection{Photocatalyst preparation}

Rutile $\mathrm{TiO}_{2} / \alpha-\mathrm{FeOOH}$ photocatalysts was obtained using $\mathrm{TiCl}_{4}$ as a precursor. Firstly $\mathrm{TiCl}_{4}$ (Shanghai Meixin Chemical Co., Ltd, China) was added dropwise into deionized water at -10 to $0{ }^{\circ} \mathrm{C}$ in an ice-water bath, with a volume ratio of $1: 2$ of $\mathrm{TiCl}_{4}$ to deionized water. The mixture was vigorous stirred for $2 \mathrm{~h}$ until it changed into a light yellow-green sol, it was aged at room temperature for 10 to $14 \mathrm{~h}$, and $\mathrm{TiCl}_{4}$ hydrosol [22] was formed.

Then the $\mathrm{TiCl}_{4}$ hydrosol was diluted by dropping appropriate amount of deionized water under stirring. And a certain mass of $\alpha-\mathrm{FeOOH}$ (Deqing Huayuan Pigment Co., Ltd., China) was dispersed into the above sol according to a molar ratio of Fe to Ti of 1:1. The mixture was divided into five equal parts, each was stirred for $2 \mathrm{~h}$ at $30,45,60,75$, or $90^{\circ} \mathrm{C}$. The precipi- tate was filtered, washed with distilled water several times to remove chlorine ions. All the samples were dried in an oven for $12 \mathrm{~h}$ at $80{ }^{\circ} \mathrm{C}$, named TY-30-2, TY-45-2, TY-60-2, TY-75-2, and TY-90-2, respectively according to the preparing temperature.

\subsection{Photocatalyst characterization}

The crystal phase, morphology, microstructure, chemical composition, and valence state of the chemical components in the photocatalysts were characterized by X-ray diffraction (XRD), scanning electron microscopy (SEM), transmission electron microscopy (TEM), energy-dispersive X-ray spectroscopy (EDS), and X-ray photoelectron spectroscopy (XPS), respectively. XRD was performed with a diffractometer (X'Pert PRO Thermo, PANalytical, Holland) using a $\mathrm{Cu} K \alpha$ radiation source $(\lambda$ $=0.1541 \mathrm{~nm}$ ) under a voltage of $40 \mathrm{kV}$ and current of $40 \mathrm{~mA}$. XRD patterns were recorded with a step size of $0.03^{\circ}$ from $15^{\circ}$ to $85^{\circ}$. TEM was performed with a high-resolution transmission electron microscope (Tecnai G2 F30 S-Twin, Philips-FEI, Netherlands) at a voltage of $300 \mathrm{kV}$. XPS was operated on a photoelectron spectrometer (Kratos AXIS Ultra DLD, Shimadzu, Japan).

\subsection{Photocatalytic performance test}

The performance of photocatalyst's absorb towards light was performed under UV-Vis light. Pure rutile $\mathrm{TiO}_{2}, \alpha-\mathrm{FeOOH}$, and samples were dispersed respectively to a solution of ethanol and deionized water with a volume ratio of 3:7, translucent solution with a concentration of $10^{-5} \mathrm{~g} / \mathrm{ml}$ was gained. The mixture was mixed by ultrasound for $5 \mathrm{~min}$, and then separated by centrifugation. The supernatant was analyzed with a UV-Vis spectrophotometer (Shimadzu UV1800, Japan) in the 200-800 nm region.

The photocatalytic performance test was carried out in a custom-made apparatus at room temperature using tungsten and deuterium lamps (wavelength 200-800 nm) as light sources. Taking $\alpha-\mathrm{FeOOH}(0.005 \mathrm{~g})$, pure rutile $\mathrm{TiO}_{2}(0.005 \mathrm{~g})$, and samples $(0.005 \mathrm{~g}$ ) added to a methyl orange solution with an initial concentration of $20 \mathrm{mg} / \mathrm{L}$ respectively in the dark. The mixture was stirred by ultrasound for $5 \mathrm{~min}$ to achieve adsorption equilibrium, and then it was irradiated with UV-vis light to commence photocatalytic degradation. Samples were taken from the reaction solution after different periods $(0,30$, $60,90,120,150$ and $180 \mathrm{~min}$ ). The amount of methyl orange remaining in the supernatant obtained after high speed centrifugation for 5 min was analyzed by UV-vis spectroscopy at $462 \mathrm{~nm}$.

\section{Results and discussion}

\subsection{XRD analysis}

Figure 1 shows XRD patterns of different samples. The intensity of the diffraction peak of rutile $\mathrm{TiO}_{2}$ at $2 \theta=27.42^{\circ}(\mathrm{PDF}$ 21-1276) increases as the preparation temperature rise. In contrast, that of $\alpha-\mathrm{FeOOH}$ (PDF 29-0713) decreases gradually 


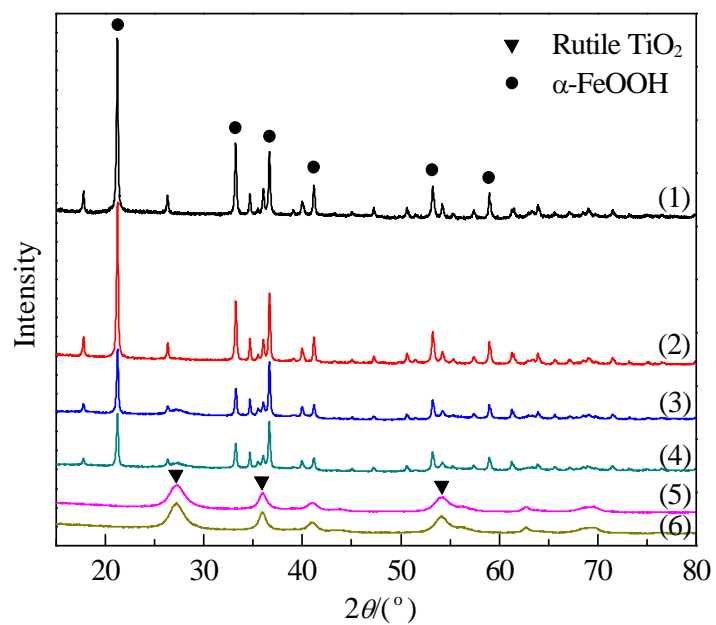

Fig. 1. XRD patterns of $\alpha$-FeOOH (1), TY-30-2 (2), TY-45-2 (3), TY-60-2 (4), TY-75-2 (5), TY-90-2 (6), prepared at $30,45,60,75$, and $90{ }^{\circ} \mathrm{C}$, respectively.

as the preparation temperature increases. At $75{ }^{\circ} \mathrm{C}$ or higher, the diffraction peaks of $\alpha$-FeOOH almost disappear; in particular, the peak at $21.224^{\circ}$ disappears completely; only the diffraction peaks of rutile $\mathrm{TiO}_{2}$ are observed. This indicates that the content of $\alpha-\mathrm{FeOOH}$ in sample decreases as the preparation temperature increases, while the content of rutile $\mathrm{TiO}_{2}$ increases gradually. As a result, the samples prepared at higher temperature are nearly composed of rutile $\mathrm{TiO}_{2}$. This can be attributed to $\alpha-\mathrm{FeOOH}$ dissolving in the acidic condition aroused by $\mathrm{TiCl}_{4}$ hydrolysis at higher temperature.

The crystalline grain size of the particles and weight percentage content of the crystal phase in the samples were estimated according to the Scherrer formula and $K$-value method, respectively; the results are presented in Table 1 . When the temperature is lower than $60^{\circ} \mathrm{C}$, the grain size of the $\alpha$-FeOOH particles is stable. When the preparation temperature exceeds $60{ }^{\circ} \mathrm{C}$, the grain size of rutile $\mathrm{TiO}_{2}$ particle is stable, and its weight percentage increases as the temperature rises. Con-
Table 1

Grain size of the (110) plane and percentage content of rutile $\mathrm{TiO}_{2} / \alpha-\mathrm{FeOOH}$ in the photocatalyst samples.

\begin{tabular}{lccccc}
\hline Preparation & \multicolumn{2}{c}{ Grain size $(\mathrm{nm})$} & & \multicolumn{2}{c}{ Weight percentage (\%) } \\
\cline { 2 - 3 } \cline { 5 - 6 } temperature $\left({ }^{\circ} \mathrm{C}\right)$ & ${\mathrm{Rutile} \mathrm{TiO}_{2}}_{2}$ & $\alpha$-FeOOH & & Rutile $\mathrm{TiO}_{2}$ & $\alpha$-FeOOH \\
\hline 30 & $-*$ & 48.4 & & - & 100 \\
45 & 7.7 & 45.9 & & 20 & 80 \\
60 & 4.6 & 43.9 & & 18 & 82 \\
75 & 4.5 & - & & 98 & 2 \\
90 & 4.8 & - & & 99 & 1 \\
\hline
\end{tabular}

* Data were not calculated because of experimental factors, for example, the peak being too weak owing to low content, which may result in error.

versely, the percentage of $\alpha-\mathrm{FeOOH}$ obviously decreases as the temperature rises. These results indicate that the grain size of rutile $\mathrm{TiO}_{2}$ and $\alpha-\mathrm{FeOOH}$ particles is related to preparation temperature. The weight percentage of rutile $\mathrm{TiO}_{2}$ in the samples is positively related to preparation temperature, whereas that of $\alpha-\mathrm{FeOOH}$ is negatively related.

\subsection{TEM analysis}

TEM images of the samples prepared at different temperatures are displayed in Fig. 2. The $\alpha$ - $\mathrm{FeOOH}$ rod has a smooth surface and a diameter of about $200 \mathrm{~nm}$, as shown in Fig. 2(a). After reaction with $\mathrm{TiCl}_{4}$ hydrosol at $30{ }^{\circ} \mathrm{C}$, the surface of the $\alpha-\mathrm{FeOOH}$ rod is coated by another substance with variable thickness (Fig. 2(b)). After reaction with $\mathrm{TiCl}_{4}$ hydrosol at $45^{\circ} \mathrm{C}$, the surface of the $\alpha-\mathrm{FeOOH}$ rod is coated with a large number of acicular rutile $\mathrm{TiO}_{2}$ particles, which form a complete, dense cladding layer with a thickness of 100-150 nm, as shown in Fig. 2 (c). When the reaction temperature was increased to $60{ }^{\circ} \mathrm{C}$, the surface of the $\alpha-\mathrm{FeOOH}$ rod was coated with many rutile $\mathrm{TiO}_{2}$ particles (Fig. 2(d)). When the reaction temperature exceeded $75{ }^{\circ} \mathrm{C}$, the microstructure of the sample changed dramatically, forming tubular structures with a length of more than $600 \mathrm{~nm}$ and diameter of more than $100 \mathrm{~nm}$. The diameter

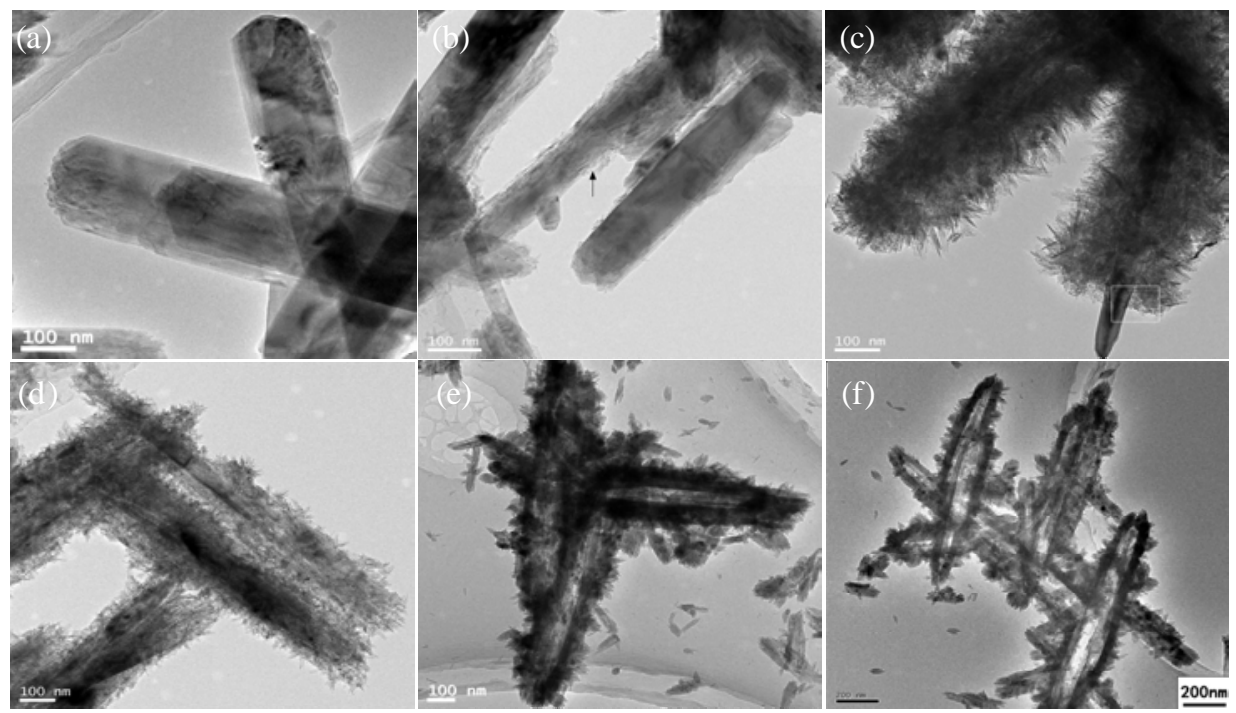

Fig. 2. TEM images of $\alpha$-FeOOH (a), TY-30-2 (b) [23], TY-45-2 (c) [23], TY-60-2 (d) [23], TY-75-2 (e), TY-90-2 (f) prepared at 30, 45, 60, 75, and 90 ${ }^{\circ} \mathrm{C}$, respectively. 


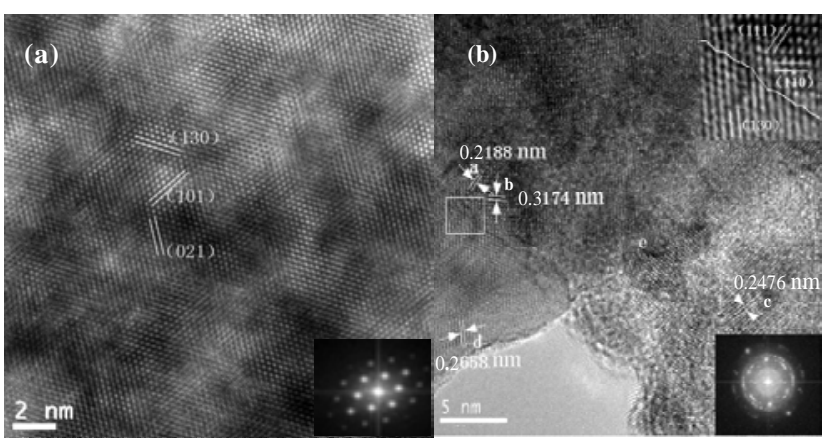

Fig. 3. Microstructures of $\alpha$-FeOOH support (a) and sample TY-45-2 (b) [23].

of the tube increases with reaction temperature, and its wall is a double layer, in which the inner layer is a complete wall structure, and the outer layer is composed of numerous particles, as illustrated in Fig. 2(e) and (f). The wall of the tubes should be rutile $\mathrm{TiO}_{2}$ according to the XRD results for the samples fabricated at higher temperature $\left(\geq 75^{\circ} \mathrm{C}\right)$. The above results indicate that the samples obtained at higher temperature are rutile $\mathrm{TiO}_{2}$ tubes. The morphology and diameter of the inner space of the rutile $\mathrm{TiO}_{2}$ tube is similar to that of the $\alpha-\mathrm{FeOOH}$ support. Both TEM and XRD results indicate that the crystal phase and microstructure of the samples is controlled by preparation temperature.

In order to confirm further the relationship between the $\alpha$-FeOOH support and rutile $\mathrm{TiO}_{2}$ cladding layer, high resolution transmission electron microscopy (HRTEM) and electron diffraction were characterized on the $\alpha$-FeOOH support and sample TY-45-2, while the electron diffraction pattern is automatic generated by Fast Fourier Transform(FFT), the results are shown in Fig. 3. The selected area electron diffraction pattern of the $\alpha-\mathrm{FeOOH}$ support indicates that it is a single crystal phase, as shown in the inset in Fig. 3(a). The support is highly crystalline and almost all of the (130), (101), and (021) crystal planes of $\alpha-\mathrm{FeOOH}$ can be seen clearly, as indicated in Fig. 3(a). The interplane distances are $0.2188,0.3174$, and $0.2472 \mathrm{~nm}$, as presented in Fig. 3(b), which are close to that of rutile $\mathrm{TiO}_{2}$ (111), (110), and (101) planes (JCPDS 21-1276), respectively. In addition, an lattice spacing of $0.2658 \mathrm{~nm}$, which is similar to that of the (130) plane of $\alpha-\mathrm{FeOOH}$, is observed (point $\mathrm{d}$ in Fig. $3(b))$. The electron diffraction pattern of TY-45-2 is shown in the inset at the lower right of Fig. 3(b), and shows the typical concentric ring of polycrystalline diffraction. This indicates that the sample is polycrystalline. The white box in Fig. 3(b) is located at the junction between rutile $\mathrm{TiO}_{2}$ and $\alpha-\mathrm{FeOOH}$. An enlargement of this region is shown in the inset at the upper right of Fig. 3(b). The dashed line is the boundary between rutile $\mathrm{TiO}_{2}$ and $\alpha-\mathrm{FeOOH}$, it is obvious that the lattice fringes from (130) plane of $\alpha-\mathrm{FeOOH}$, and (111), (110) plane of rutile $\mathrm{TiO}_{2}$ cross each other, which implies that there is a coherent relationship between rutile $\mathrm{TiO}_{2}$ and $\alpha-\mathrm{FeOOH}$ phases.

At the microscale, these results prove that the interaction between the $\alpha$-FeOOH support and rutile $\mathrm{TiO}_{2}$ coating layer involves chemical bonding rather than physical adsorption. This is because $\mathrm{TiCl}_{4}$ forms hydroxy intermediate Ti(OH) $)_{x}(x \leq$ 4) during hydrolysis. The hydroxy intermediate reacts with the hydroxyl group of $\alpha-\mathrm{FeOOH}$, causing dehydration condensation to occur during sample preparation. This reaction results in the formation of Ti-O-Fe bonds, which will be located at the interface between rutile $\mathrm{TiO}_{2}$ and $\alpha-\mathrm{FeOOH}$ and form electron trap, which is a kind of cation defect. This process is the main reason why the rutile $\mathrm{TiO}_{2}$ phase appears at $30{ }^{\circ} \mathrm{C}$ in this system.

\subsection{EDS analysis}

EDS results obtained for samples TY-45-2 and TY-90-2 are presented in Fig. 4. Figure 4C-E clearly show that the distribution of 0 in sample TY-45-2 is uniform, and its distribution outline fits well with the morphology of the sample. The density distribution of $\mathrm{Ti}$ and $\mathrm{Fe}$ is different: that of $\mathrm{Ti}$ is lower at the

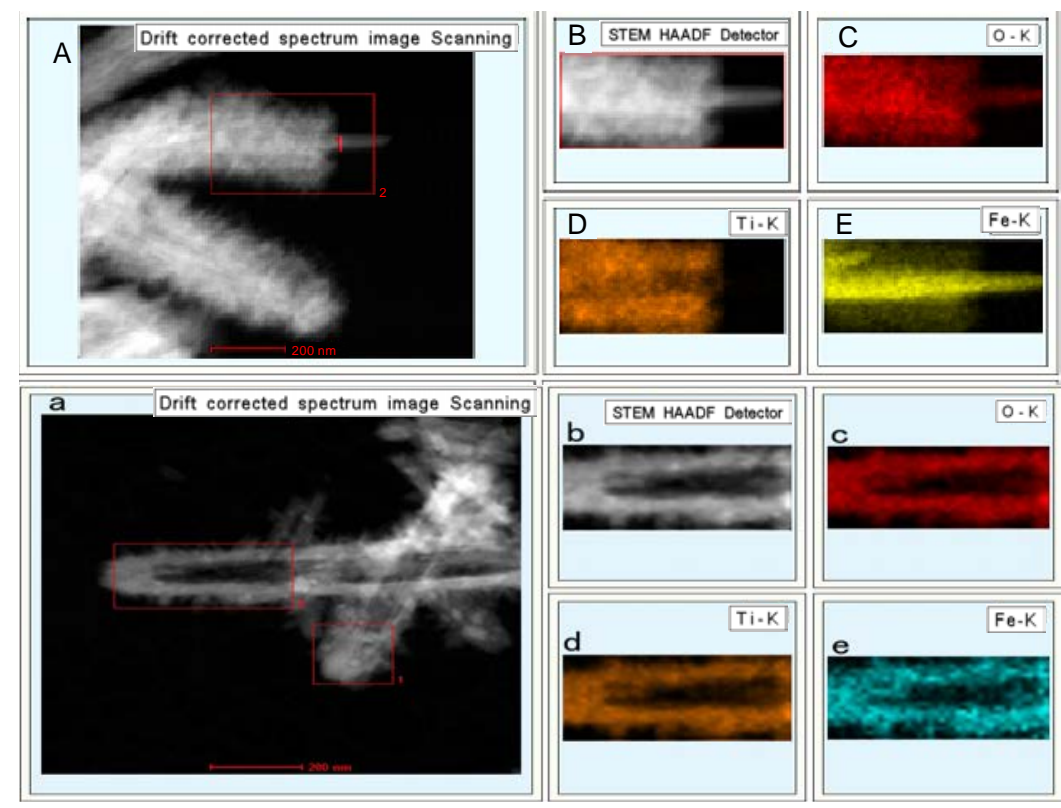

Fig. 4. EDS of samples TY-45-2 (A-E) [23] and TY-90-2 (a-e). 

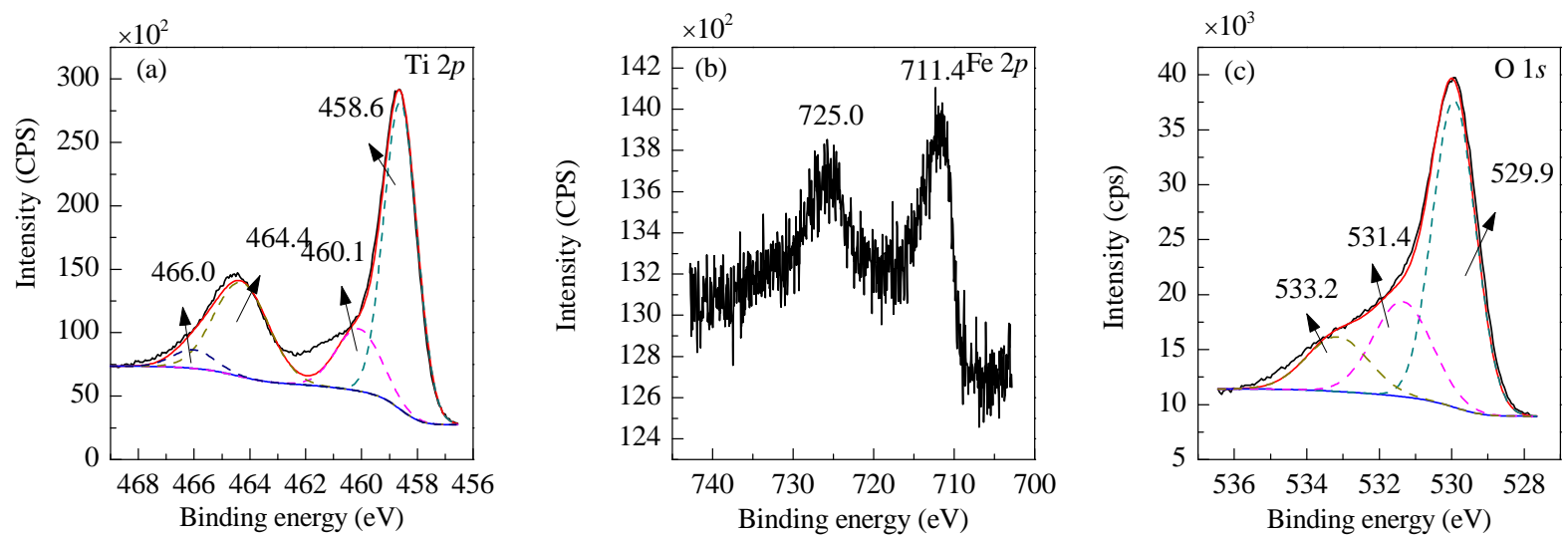

Fig. 5. Ti $2 p$ (a), Fe $2 p$ (b), and $01 s$ (c) XPS profiles of sample TY-90-2.

inner core and higher at the outer side; in contrast, that of Fe is higher at the inner core and lower at the outside. Taking the XRD and TEM results for sample TY-45-2 into account, the $\alpha$-FeOOH support is coated by rutile $\mathrm{TiO}_{2}$ to form a composite structure.

Figure $4 \mathrm{c}-\mathrm{e}$ indicates that the distribution outlines of $\mathrm{O}, \mathrm{Ti}$, and Fe in TY-90-2 are similar to the corresponding elements in TY-45-2, but their density distributions are different. The densities of $\mathrm{O}$ and Ti element are relatively high, whereas that of $\mathrm{Fe}$ is relatively low. Their similar distribution outlines can be attributed to the dissolving of $\alpha-\mathrm{FeOOH}$ in acidic condition during the hydrolysis of $\mathrm{TiCl}_{4}$ at higher temperature, which allows $\mathrm{Fe}$ to enter the $\mathrm{TiO}_{2}$ lattice as $\mathrm{Fe}^{3+}$ cations. In Fig. 4a, the outline of the inner space of the rutile $\mathrm{TiO}_{2}$ tube is similar to the morphology of the $\alpha-\mathrm{FeOOH}$ support, but its size is slightly smaller. This indirectly suggests that the hollow space inside the rutile $\mathrm{TiO}_{2}$ tube is aroused by $\alpha-\mathrm{FeOOH}$ support partially dissolving.

\subsection{XPS analysis}

High-resolution Ti $2 p$, Fe $2 p$, and $01 s$ XPS profiles of sample TY-90-2 and fitted curves are shown in Fig. 5. Figure 5(a) shows Ti $2 p$ XPS with typical bimodal structure, containing a Ti $2 p_{3 / 2}$ peak at low binding energy and Ti $2 p_{1 / 2}$ peak at high binding energy. Two curves can be drawn by sub-peak fitting, revealing that $\mathrm{Ti}$ is present in two chemical states. 458.6 and $464.4 \mathrm{eV}$ correspond to the binding energy of $\mathrm{TiO}_{2}[24,25]$, while 460.1 and $466.0 \mathrm{eV}$ correspond to the binding energy of $\mathrm{TiO}_{x}$ [26]. These results show that $\mathrm{TiO}_{2}$ has converted into $\mathrm{TiO}_{x}$ and a low valence state of $\mathrm{Ti}$ appears. Formation of $\mathrm{TiO}_{x}$ is related to the formation and rupture of $\mathrm{Ti}-\mathrm{O}-\mathrm{Fe}$ bonds and the thermal diffusion properties of $\mathrm{Ti}^{4+}$ and $\mathrm{Fe}^{3+}$ during sample preparation [27].

Figure 5(b) shows an Fe $2 p$ XPS profiles of sample TY-90-2. 725 and $711.4 \mathrm{eV}$ correspond to the binding energies of $\mathrm{Fe}$ $2 p_{3 / 2}$ and $\mathrm{Fe} 2 p_{1 / 2}$, respectively. Therefore, only one chemical state of $\mathrm{Fe}$ is present in the sample: $\mathrm{Fe}^{3+}$. The binding energies of the Fe peaks do not deviate obviously from that expected for $\mathrm{Fe}^{3+}$. This is because the difference of electronegativity between $\mathrm{Ti}$ and $\mathrm{Fe}$ is not evident, and the formation of $\mathrm{Ti}-\mathrm{O}-\mathrm{Fe}$ bonds does not enable the inner electrons of Fe to be shielded by the oxygen bridging bond [28,29].
Figure 5(c) shows the $01 s$ XPS profiles of sample TY-90-2. Three chemical states of 0 are present in sample TY-90-2. $529.5 \mathrm{eV}$ corresponds to the binding energy of $\mathrm{TiO}_{2}$ [30], 531.4 $\mathrm{eV}$ corresponds to the binding energy of $\mathrm{OH}$ [31], and $533.2 \mathrm{eV}$ is attributed to the binding energy of adsorbed oxygen $\left(\mathrm{H}_{2} \mathrm{O}\right.$, $\mathrm{O}_{2}$ ) because of its high binding energy [31]. Based on peak areas, $01 s$ exists mainly as lattice oxygen (Ti-O-Ti), which is consistent with the results of Ti $2 p$ XPS, XRD, and TEM. In addition, a certain amount of $\mathrm{OH}$ is present on the surface of the rutile $\mathrm{TiO}_{2}$ tubes according to XPS results. The presence of $\mathrm{OH}$ should improve the photocatalytic activity of the sample. In addition, the physical adsorption of oxygen shows that the rutile $\mathrm{TiO}_{2}$ tubes fabricated by hydrolysis and precipitation should exhibit high activity and adsorption capacity $[31,32]$.

Taking all of the characterization results into account, rutile $\mathrm{TiO}_{2}$ can effectively coat $\alpha-\mathrm{FeOOH}$ at low temperature. The acid solution produced during the hydrolysis of $\mathrm{TiCl}_{4}$ at high temperature can dissolve $\alpha-\mathrm{FeOOH}$, and then $\mathrm{Fe}^{3+}$ can enter into the crystal lattice of rutile $\mathrm{TiO}_{2}$ tubes as a dopant cation during sample preparation. The structure of the samples changes with preparation temperature. When the temperature is low $(\leq 45$ ${ }^{\circ} \mathrm{C}$ ), a composite structure forms. At intermediate temperature $\left(60{ }^{\circ} \mathrm{C}\right)$, a mixture of composite and doped structure is produced, and when the temperature is high $\left(\geq 75^{\circ} \mathrm{C}\right)$, only the doped structure forms.

\subsection{UV-Vis spectral analysis}

Figure 6 shows UV-Vis absorption curves of the TY-2 samples, P25, and $\alpha-\mathrm{FeOOH}$. P25 absorbs in the UV region with a peak wavelength of $326 \mathrm{~nm}$, but hardly absorbs in the visible region. $\alpha-\mathrm{FeOOH}$ exhibits a weak absorption peak at $315 \mathrm{~nm}$, and a strong, broad one in the visible range centered at $440 \mathrm{~nm}$. Samples TY-30-2, TY-45-2, and TY-60-2 exhibit absorption peaks at 287, 308, and $300 \mathrm{~nm}$, respectively. Their peak positions show a small blue shift compared with that of P25 at 326 $\mathrm{nm}$ and $\alpha-\mathrm{FeOOH}$ at $315 \mathrm{~nm}$. In addition, the samples absorb over a wide range of 363-452, 362-458, and 365-446 nm for samples TY-30-2, TY-45-2, and TY-60-2, respectively. Their peak positions are red-shifted compared with that of $\alpha-\mathrm{FeOOH}$ at $440 \mathrm{~nm}$, and their absorption edges extend to 727, 823, and $821 \mathrm{~nm}$. Samples TY-75-2 and TY-90-2 exhibit strong absorp- 


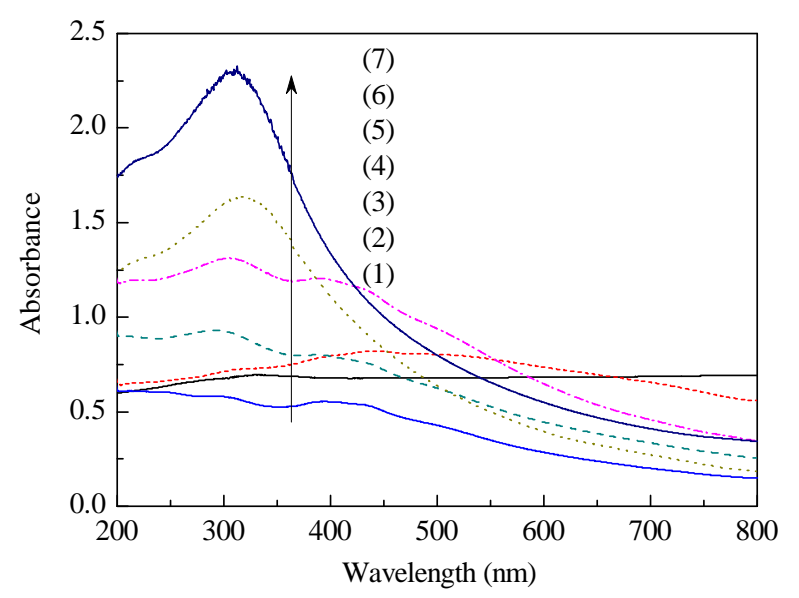

Fig. 6. UV-Vis absorption curves for Y-90-2 (1), TY-75-2 (2), TY-45-2 (3), TY-60-2 (4), $\alpha$-FeOOH (5), rutile $\mathrm{TiO}_{2}(6)$, and TY-30-2 (7).

tion peaks at 318 and $310 \mathrm{~nm}$, respectively, and their absorption edges are at 573 and $515 \mathrm{~nm}$, extending into the visible region.

\subsection{Photocatalytic degradation of methyl orange}

Figure 7shows the results of the photocatalytic degradation of methyl orange by different TY-2 samples. The photocatalytic degradation of methyl orange by pure rutile $\mathrm{TiO}_{2}$ is poor. After irradiation for $180 \mathrm{~min}$, only $10 \%$ of methyl orange is degraded. The photocatalytic degradation of methyl orange by the five $\mathrm{TiO}_{2} / \alpha-\mathrm{FeOOH}$ samples can be divided into three categories according to their characteristics after illumination for $60 \mathrm{~min}$. (1) The degradation effect increases as the illumination time increases such as sample TY-45-2. (2) When the illumination time is between 60 and $150 \mathrm{~min}$, the degradation proceeds smoothly, and then increases as the illumination time increases further. Samples TY-30-2 and TY-90-2 fall into this category. (3) The degradation effect increases continuously as illumination time progresses. Samples TY-60-2 and TY-75-2 are typical of this category. The degradation of methyl orange by TY-60-2 reaches $79.7 \%$ after illumination for $180 \mathrm{~min}$.

Sample TY-30-2 is a composite material of $\mathrm{TiO}_{2}$ and $\alpha-\mathrm{FeOOH}$, where $\mathrm{TiO}_{2}$ particles are distributed on the surface of $\alpha-\mathrm{FeOOH}$ and do not form a complete cladding (Fig. 2(b)). As a result, its photocatalytic degradation performance is poor. Sample TY-45-2 is a composite material of $\mathrm{TiO}_{2}$ and $\alpha-\mathrm{FeOOH}$, where acicular $\mathrm{TiO}_{2}$ particles are distributed over the entire surface of $\alpha-\mathrm{FeOOH}$ to form a core-shell structure (Fig. 2(c)). Electron traps form at the interface between $\mathrm{TiO}_{2}$ and $\alpha-\mathrm{FeOOH}$, which are a kind of cation defect. This defect can effectively hinder the recombination of photogenerated electron-hole pairs, improving the photocatalytic efficiency of the catalyst [31-35]. Chen et al. [36] reported that many unsaturated oxygen atoms exist on the surface of nanoscale iron oxides. The same is true for the surface of nanoscale titanium oxide too. As a result, the binding energy of Ti-O-Fe at the interface between $\mathrm{TiO}_{2}$ and $\alpha$-FeOOH is strong. In addition, compared with $\alpha-\mathrm{FeOOH}$, this sample contains more dislocations

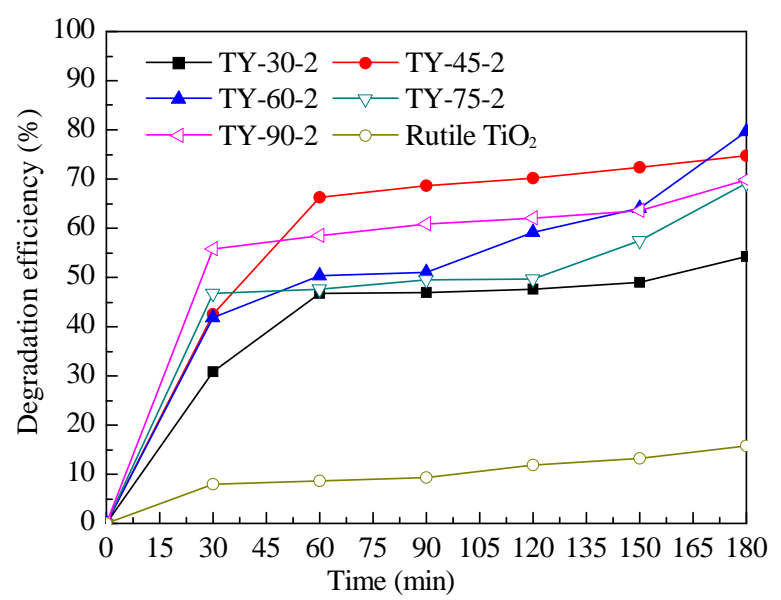

Fig. 7. Photodegradation of methyl orange by samples irradiated with two lamps (wavelength range of 200-800 nm).

and surface defects (e in Fig. 3(b)), which can behave as active sites during photocatalysis. Therefore, the photocatalytic performance of TY-45-2 is improved compared with that of $\mathrm{TiO}_{2}$ alone.

$\mathrm{TiO}_{2}$ particles of the sample TY-60-2 were distributed over the entire surface of $\alpha-\mathrm{FeOOH}$ to form a core-shell structure (Fig. 2(d)). XPS results for this sample indicated iron ions were doped in the rutile $\mathrm{TiO}_{2}$ lattice, so sample TY-60-2 is a mixture of both composite and doped structures. $\mathrm{Fe}^{3+}$ doped into the $\mathrm{TiO}_{2}$ crystal lattice causes it to distort. Considering energy band theory, the interaction between the $t_{2 \mathrm{~g}}$ level of $\mathrm{Ti}^{4+}$ and $p-\pi$ level of $\mathrm{O}^{2-}$ in the lattice results in the formation of $\pi$ and $\pi^{*}$ bands, which are the valence and conduction bands, respectively, of the $\mathrm{TiO}_{2}$ semiconductor. A new $d$ band will form in the band gap of $\mathrm{TiO}_{2}$ when low valence $\mathrm{Fe}^{3+}$ replaces $\mathrm{Ti}^{4+}$ in the $\mathrm{TiO}_{2}$ lattice. The $d$ band does not overlap with the $\pi^{*}$ band because the d level of $\mathrm{Ti}^{4+}$ lies lower than the $\pi^{*}$ band in the lattice. As a result, many separate impurity bands was formed in the forbidden band, which can overlap with the conduction band of $\mathrm{TiO}_{2}$. In this case, electrons will be photogenerated by the semiconductor after absorption of a relatively small amount of energy, and its response range to light will widen, so its photocatalytic activity will be enhanced.

These results imply that the photocatalytic activity and efficiency of the sample with a mixed composite/doped structure is improved because it can prolong the lifetime of photogenerated holes and electrons; in other words, the doped and composite structures coordinate well.

This is the main reason why the absorption edge of TY-60-2 extends into the visible region, and why its photocatalytic degradation performance is higher than that of the other samples. Besides, the structure of samples TY-75-2 and TY-90-2 is tubular and doped with iron. The photocatalytic performance of these samples is better than that of samples with a core-shell structure, and similar to that of the sample with a mixture of composite and doped structures, which is correlated to its structural characteristics. In summary, the photocatalytic per-

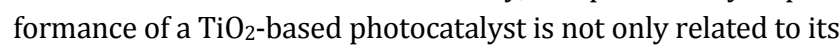
crystal phase, but also correlated to its structure. 


\section{Conclusions}

$\mathrm{TiO}_{2} / \alpha-\mathrm{FeOOH}$ photocatalysts with controlled crystal phase and microstructure were prepared by hydrolysis and precipitation at specific reaction temperatures. At low temperature, a composite material with core-shell structure containing rutile $\mathrm{TiO}_{2}$ as a shell and $\alpha-\mathrm{FeOOH}$ as a core was fabricated. At higher temperature, $\mathrm{Fe}^{3+}$-doped rutile $\mathrm{TiO}_{2}$ tubes formed, and at intermediate temperature, the resulting photocatalyst contained a mixture of composite and doped structures. Combining rutile $\mathrm{TiO}_{2}$ with $\alpha$-FeOOH significantly improved the optical absorption of the samples, and the absorption edge of $\mathrm{Fe}^{3+}$-doped rutile $\mathrm{TiO}_{2}$ tubes was extended to the visible region. Among the above three different structures, the sample with both composite and doped structures exhibits the highest activity, while the composite structure exhibits poor activity. In summary, the structure of the photocatalysts affects its photocatalytic performance for degradation of methyl orange.

\section{References}

[1] Fujishima A, Honda K. Nature, 1972, 238: 37

[2] Carey J H, Lawrence J. Bull Environ Contarn Toxical, 1976, 16: 697

[3] Frank S N, Bard A. J Am Chem Soc, 1977, 99: 303

[4] Chen X B. Chin J Catal (陈晓波. 催化学报), 2009, 30: 839

[5] Liu C Y. Nano Photocatalysis and Photocatalytic Materials for Environmental Purification. Beijing: Chem Ind Press (刘春艳. 纳米 光催化及光催化环境净化材料. 北京: 化学工业出版社), 2007. 125

[6] Herrmann J M, Guillard C, Disdier J, Lehaut C, Malato S, Blanco J. Appl Catal B, 2002, 35: 281

[7] Chong M N, Jin B, Chow C W K, Saint C. Water Res, 2010, 44: 2997

[8] Ding Z, Feng X G, Chen X D, Fu D G, Yuan C W. Environ Sci (丁震, 冯 小刚, 陈晓东, 付德刚, 袁春伟. 环境科学), 2006, 27: 1814
[9] Liu G, Wang L Z, Yang H G, Chen H M, LU G Q. J Mater Chem, 2010, 20: 831

[10] Zhang R H, Wang Q Liang J, Li Q, Dai J F, Li W X. Phys B, 2012, 407: 2709

[11] Zhang D F, Zeng F. Russ J Phy Chem A, 2011, 85: 1825

[12] Fan X X, Chen X Y, Zhu S P, Li Z S, Yu T, Ye J H, Zou Z G. J Mol Catal A, 2008, 284: 155

[13] Klosek S, Raftery D. J Phys Chem B, 2001, 105: 2815

[14] Li X H, Zhang H D, Zheng X X, Yin Z Y, Wei L. J Environ Sci, 2011, 23: 1919

[15] Liu S X, Chen X Y.J Hazard Mater, 2008, 152: 48

[16] Liu R L, Ye H Y, Xiong X P, Liu H Q. Mater Chem Phys, 2010, 121: 432

[17] Tada H, Jin Q L, Nishijima H, Yamamoto H, Fujishima M, Okuoka S I, Hattori T, Sumida Y, Kobayashi H. Angew Chem, Int Ed, 2011, 50: 3501

[18] Yu X X, Liu S W, Yu J G. Appl Catal B, 2011, 104: 12

[19] Sajjad A K L, Shamaila S, Tian B Z, Chen F, Zhang J L. Appl Catal B, 2009, 91: 397

[20] Liang K, Tang L Y, Li G H. J Synthetic Crystals (梁凯, 唐丽永, 李国 华. 人工晶体学报), 2011, 40: 1011

[21] Rawal S B, Chakraborty A K, Lee W I. Bull Korean Chem Soc, 2009, 30: 2613.

[22] Li G H, Zheng Y F, Ma C A, Tian W. Trans Nonferrous Met Soc China, 2008, 18: 469

[23] Wang Y F, Wang W, Zheng Y F, Li G H. J Inorg Mater (王燕飞, 王卫, 郑遗凡, 李国华. 无机材料学报), 2013, 28: 177

[24] Bender H, Chen W D, Portillo J, Van den Hove J, Vandervorst W. Appl Surf Sci, 1989, 38: 37

[25] Perron H, Vandenborre J, Domain C, Drot R, Roques J, Simoni E, Ehrhardt J J, Catalette H. Surf Sci, 2007, 601: 518

[26] Xu W X, Zhu S, Fu X C. Appl Surf Sci, 1998, 136: 194

[27] Hsiung T L, Wang H P, Wang H C. Radiat Phys Chem, 2006, 75: 2042

[28] Raeburn S P, Ilton E S, Veblen D R. Geochim Cosmochim Acta, 1997, 61: 4519

\section{Graphical Abstract}

Chin. J. Catal., 2013, 34: 1076-1086 doi: 10.1016/S1872-2067(12)60569-5

Preparation and photocatalytic activity of rutile $\mathrm{TiO}_{2}$ and goethite composite photocatalysts

XIE Weimiao, CHEN Hui, ZHANG Xuanhui, HU Xianchao, LI Guohua*

Zhejiang University of Technology

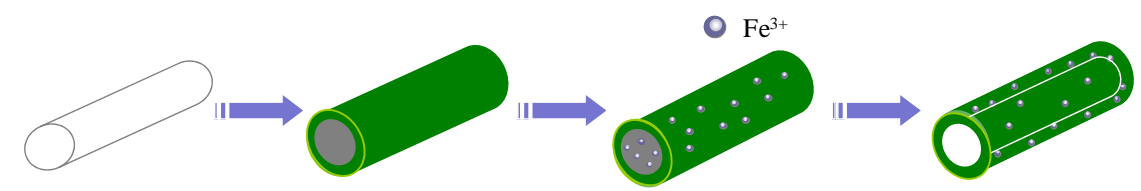

Goethite microrod Goethitemicrorod coated by $\mathrm{Fe}^{3+}$ doped into the lattice Iron doping rutile $\mathrm{TiO}$ as supports rutile $\mathrm{TiO}_{2}$ particles at $45^{\circ} \mathrm{C}$ of rutile $\mathrm{TiO}_{2}$ at $60{ }^{\circ} \mathrm{C}$ nanotube forms at $75^{\circ} \mathrm{C}$
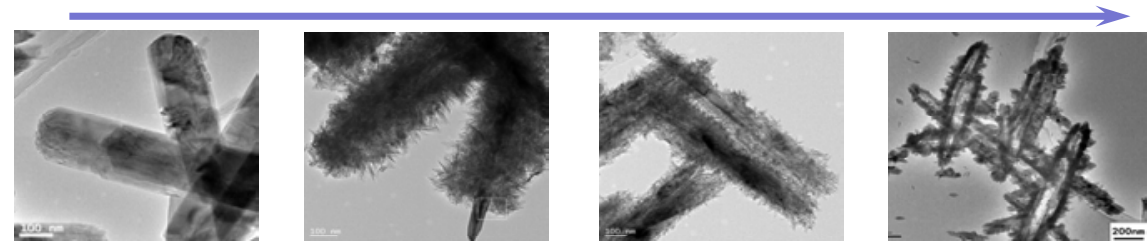

The structure of rutile $\mathrm{TiO}_{2}$ and $\alpha$-FeOOH composite photocatalysts can be controlled by adjusting reaction temperature, and their photocatalytic activity is maximized when they possess a core-shell structure with $\mathrm{Fe}^{3+}$ doping. 
[29] Abdel Samad H, Watson P R. Appl Surf Sci, 1998, 136: 46

[30] Ettireddy P R, Ettireddy N, Mamedov S. Boolchand P, Smirniotis P G. Appl Catal B, 2007, 76: 123

[31] Kloprogge J T, Duong L V, Wood B J. Frost R L. J Colloid Interface Sci, 2006, 296: 572

[32] Huang J D, Wen S H, Liu J Y. J Nat Gas Chem, 2012, 21: 302

[33] Krishnan V, Heislbetz S, Natile M M, Glisenti A, Bertagnolli H. Ma- ter Chem Phys, 2005, 92: 394

[34] Chen X Y, Liu S X, Chen X, Sun C L. Acta Phys-Chim Sin (陈孝云, 刘 守新, 陈䂀, 孙承林. 物理化学学报), 2006, 22: 517

[35] Heinen O, Holland-Moritz D, Herlach D M. Mater Sci Eng A, 2007, 449: 662

[36] Chen J Y, Peng T Z. Acta Chim Sin (陈金媛, 彭图治. 化学学报), 2004, 62: 2093

\title{
二氧化钛与针铁矿复合光催化材料的制备与光催化性能
}

\author{
谢伟沝 ${ }^{\mathrm{a}}$, 陈 辉 ${ }^{\mathrm{a}}$, 张炫辉 ${ }^{\mathrm{a}}$, 胡仙超 ${ }^{\mathrm{c}}$, 李国华 ${ }^{\mathrm{a}, \mathrm{b},{ }^{*}}$

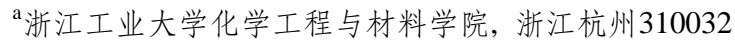

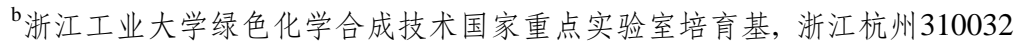 \\ c浙江工业大学分析测试中心, 浙江杭州310032
}

摘要: 以四氯化钛为钛源, 针铁矿 ( $\alpha-\mathrm{FeOOH})$ 为载体, 采用水解沉淀法制备了金红石相二氧化钛 $\left(\mathrm{Ti}_{2} \mathrm{O}\right)$ 与 $\alpha-\mathrm{FeOOH}$ 的复合光催化 材料, 并采用X射线衍射、扫描电子显微镜、透射电子显微镜、X射线能量散射谱和X射线光电子能谱对样品进行了表征. 结果表 明, 低温下, 金红石相 $\mathrm{Ti}_{2} \mathrm{O}$ 包覆于 $\alpha-\mathrm{FeOOH}$ 表面, 并形成复合结构; 较高温下, 铁离子进入金红石相 $\mathrm{Ti}_{2} \mathrm{O}$ 晶格, 并形成铁掺杂金红 石相 $\mathrm{Ti}_{2} \mathrm{O}$ 纳米管; 中温下, 样品兼有复合和掺杂两者特征. 在室温下以甲基橙为降解对象, 采用铇灯+氛灯 (波长200 800 $\mathrm{nm}$ )为光 源, 对样品的光催化活性进行了测试. 结果表明, 样品对甲基橙的光催化降解效果良好; 与纯 $\alpha-\mathrm{FeOOH}$ 和金红石相 $\mathrm{Ti}_{2} \mathrm{O}$ 相比, 不同 结构样品的光催化活性均有所提高, 其中, 复合兼掺杂型样品的光催化活性最高. 由此可见, 与 $\alpha$-FeOOH复合和铁掺杂是提高 $\mathrm{Ti}_{2} \mathrm{O}$ 光催化活性的有效途径.

关键词：二氧化钛；针铁矿；复合材料；光催化性能; 甲基橙

收稿日期: 2012-10-21. 接受日期: 2013-03-12. 出版日期: 2013-06-20.

*通讯联系人.电话：(0571)88320418; 传真：(0571)88320544; 电子信箱：nanozjut@zjut.edu.cn

基金来源：国家自然科学基金(21173193); 浙江省自然科学基金(Y4080209, Y406094); 浙江省化学工程与新材料研究生教育创新 示范基地(2004); 浙江省绿色化学合成技术重点科技创新团队专项(G1201101001601/001)..

本文的英文电子版由Elsevier出版社在ScienceDirect上出版(http://www.sciencedirect.com/science/journal/18722067).

\section{1. 前言}

如何解决环境保护问题是当今社会所面临的一个 重要课题. 在未来二十年中, 环境污染治理将成为最急 于优先解决的全球性问题 ${ }^{[13]}$. 应用半导体光催化材料 治理环境污染是最有前途的技术方法之一 ${ }^{[4 \sim 6]}$. 在众多 半导体光催化剂材料中, 纳米 $\mathrm{TiO}_{2}$ 具有无毒、光化学性 质稳定、催化效率高、氧化能力强, 且无二次污染等特 点, 因而广泛应用于光催化处理水和空气等环境污染问 题中 ${ }^{[7,8]}$.

然而, 纳米 $\mathrm{TiO}_{2}$ 半导体光催化材料在实际应用中存 在明显的不足.一方面, $\mathrm{TiO}_{2}$ 带隙较宽(锐钛矿可达3.2 $\mathrm{eV})$, 其吸收阈值为 $387.5 \mathrm{~nm}$, 只能吸收紫外光, 在可见光 范围基本没有响应, 对太阳光利用率低(约3\% 5\%); 另 一方面, $\mathrm{TiO}_{2}$ 光生载流子的寿命短, 在纳秒(ns)到皮秒 (ps)时间范围内, 复合率高. 从而大大降低了纳米 $\mathrm{TiO}_{2}$ 的 光催化效率. 因此, 如何提高光催化效率是当今纳米 $\mathrm{TiO}_{2}$ 光催化材料应用研究的热点和难点之一, 也是其走 向实际应用的关键.
国内外学者通过控制晶体结构和表面物化性质 ${ }^{[9]}$, 如掺杂金属离子 ${ }^{[10 ~ 12]}\left(\right.$ 如 $\mathrm{Fe}^{3+}, \mathrm{Cr}^{3+}, \mathrm{Mn}^{2+}$ 和 $\mathrm{Co}^{2+}$ 等具有 全充满或半充满电子构型的过渡金属离子)和非金属元 素(如 $N, S, F$ 和V等) ${ }^{[13 \sim 15]}$, 及 $\mathrm{TiO}_{2}$ 与其它带隙较窄的半导 体复合等途径, 以减小 $\mathrm{TiO}_{2}$ 光催化材料的带隙, 并降低 光生载流子复合率. 近年来 $\mathrm{Fe}_{2} \mathrm{O}_{3} / \mathrm{TiO}_{2}{ }^{[16]}, \mathrm{TiO}_{2} / \mathrm{SiO}_{2}{ }^{[17]}$, $\mathrm{TiO}_{2} / \mathrm{WO}_{3}{ }^{[18]}, \mathrm{TiO}_{2} / \mathrm{ZnO}^{[19]}$ 等多相复合体系已得到广泛 研究. 在众多带隙较窄的金属氧化物半导体中, $\alpha$-FeOOH因带隙较窄 $(2.6 \mathrm{eV})$, 可作为 $\mathrm{TiO}_{2}$ 的载体之一. 若将它与 $\mathrm{TiO}_{2}$ 复合可减小光催化材料的禁带宽度, 使复 合材料的光响应范围扩展至可见光 ${ }^{[20,21]}$. 此外, $\alpha-\mathrm{FeOOH}$ 也可为金属离子掺杂提供 $\mathrm{Fe}^{3+}$, 以提高 $\mathrm{TiO}_{2}$ 光 催化材料的性能.

人们对 $\mathrm{TiO}_{2} / \alpha-\mathrm{FeOOH}$ 光催化材料进行了深入的研 究. 梁凯等 ${ }^{[20]}$ 利用水解沉淀法制备了核壳结构的 $\mathrm{TiO}_{2} / \mathrm{FeOOH}$ 复合材料, 复合后产生明显的协同效应, 光 催化降解有机物的能力明显提高. Rawal等 ${ }^{[21]}$ 在研究中 发现, $\mathrm{TiO}_{2} / \mathrm{FeOOH}$ 纳米复合材料在可见光 $(\lambda \geqslant 420 \mathrm{~nm})$ 下可将气态异丙醇降解为 $\mathrm{CO}_{2}$, 表现出较高的光催化降 
解效率. 但现有文献报道中, 很少涉及制备参数与 $\mathrm{TiO}_{2} /$ $\alpha-\mathrm{FeOOH}$ 光催化材料降解有机物性能的关系, 尤其是制 备参数与其微结构的关系以及微结构与性能的关联.

本文以四氯化钛 $\left(\mathrm{TiCl}_{4}\right)$ 为前躯体, $\alpha-\mathrm{FeOOH}$ 为载体, 制备复合型和掺杂型 $\mathrm{TiO}_{2} / \alpha-\mathrm{FeOOH}$ 光催化材料, 考察了 制备条件对其光催化降解甲基橙活性的影响, 探索了复 合型和掺杂型光催化材料性能与其结构的关联性.

\section{2. 实验部分}

\section{1. 样品的制备}

以市售 $\mathrm{TiCl}_{4}$ (上海美心化工股份有限公司, 化学纯) 为前驱体, 在 $-10 \sim 0{ }^{\circ} \mathrm{C}$ 冰水浴中将其缓慢滴加到去离子 水中, 两者体积比为 $1: 2$, 并充分搅拌, 滴加完毕后持续摚 拌 $2 \mathrm{~h}$, 待体系转变成为浅黄绿色溶胶后, 于室温老化 10 14 h, 即得 $\mathrm{TiCl}_{4}$ 水溶胶 ${ }^{[22]}$.

在搅拌下将适量去离子水滴到上述 $\mathrm{TiCl}_{4}$ 水溶胶中, 获得稀释后的水溶胶. 按 $\mathrm{Fe} / \mathrm{Ti}$ 摩尔比为 $1: 1$ 将 $\alpha-\mathrm{FeOOH}$ (升华集团德清华源颜料有限公司)分散到上述稀释的溶 胶中, 再将其均匀地分为 5 等份, 分别在 $30,45,60,75$ 和 $90{ }^{\circ} \mathrm{C}$ 摚拌反应 $2 \mathrm{~h}$. 静置、抽滤和水洗, 如此循环数遍, 直 止无氯离子检出, 然后在 $80{ }^{\circ} \mathrm{C}$ 干燥 $12 \mathrm{~h}$, 即得 TY-30-2, TY-45-2, TY-60-2, TY-75-2和TY-90-2样品.

\section{2. 样品的表征}

采用X射线衍射(XRD)、透射电子显微镜(TEM)、X 射线能量散射谱(DES)和X射线光电子能谱(XPS)对样品 的晶相组成、形貌、微结构、化学组成和价态进行了表 征. 其中, XRD分析在荷兰PANalytical公司X'Pert PRO 型X射线衍射仪上进行, $\mathrm{Cu} K_{\alpha}$ 射线 $(\lambda=0.1541 \mathrm{~nm})$, 电 压 $40 \mathrm{kV}$, 电流 $40 \mathrm{~mA}$, 步长 $0.03^{\circ}$, 范围 $15^{\circ} \sim 85^{\circ}$; TEM为 荷兰Philips-FEI公司Tecnai G2 F30 S-Twin型, 300 kV; XPS表征在日本岛津公司Kratos AXIS Ultra DLD型光电 子能谱仪上进行.

\section{3. 性能测试}

紫外-可见(UV-Vis)光吸收性能测试：按体积比为 3:7配制乙醇/去离子水混合液, 将纯金红石相 $\mathrm{TiO}_{2}$ 、 $\alpha-\mathrm{FeOOH}$ 和样品分散于其中, 配制浓度为 $10^{-5} \mathrm{~g} / \mathrm{ml}$ 的半 透明溶液, 超声 5 min后离心并取上层清液, 在Shimadzu UV1800紫外可见分光光度计(UV-Vis)上进行光吸收性 能测试, 扫描范围200 800 nm.

光催化反应在自制的装置中进行. 在室温下以铇灯 +氝灯(波长200 800 nm) 为降解光源, 称取载体、纯金红 石相 $\mathrm{TiO}_{2}$ 和各种样品各 $0.005 \mathrm{~g}$, 在避光条件下将它们加
到初始浓度为 $20 \mathrm{mg} / \mathrm{L}$ 甲基橙溶液中, 超声 $5 \mathrm{~min}$, 使之达 到吸附-脱附平衡. 然后在上述光源照射下分别进行光 催化降解反应, 并在 $0,30,60,90,120,150$ 和 $180 \mathrm{~min}$ 时取 一定体积的已降解悬浊液, 经高速离心分离后取上层清 液, 在紫外可见分光光度计上进行吸光度测试, 吸光度 检测波长为 $462 \mathrm{~nm}$.

\section{3. 结果与讨论}

\subsection{XRD结果}

图1为各样品的XRD谱. 由图可见, 随着制备温度 的升高, 金红石相 $\mathrm{TiO}_{2}$ (PDF 21-1276)特征衍射峰(2 $\theta=$ $27.42^{\circ}$ ) 逐渐增强, $\alpha$-FeOOH (PDF 29-0713) 衍射峰则逐渐 减弱; 在高温 $\left(\geqslant 75^{\circ} \mathrm{C}\right)$ 制备的样品中, $\alpha-\mathrm{FeOOH}$ 衍射峰 基本消失, 尤其是 $2 \theta=21.224^{\circ}$ 处特征衍射峰彻底消失, 仅出现金红石相 $\mathrm{TiO}_{2}$ 的衍射峰. 这说明随着制备温度的 升高, 所得样品中 $\alpha-\mathrm{FeOOH}$ 逐渐减少, 金红石相 $\mathrm{TiO}_{2}$ 逐 渐增加, 高温下样品基本由金红石相 $\mathrm{TiO}_{2}$ 组成. 这可能 是由于高温下 $\mathrm{TiCl}_{4}$ 水解产生的酸强度大, 致使 $\alpha-\mathrm{FeOOH}$ 溶解所致.

利用谢乐公式和 $K$ 值法计算了样品晶粒度大小和相 对百分含量, 结果见表1. 可以看到, 当制备温度高于 60 ${ }^{\circ} \mathrm{C}$ 时, 所得样品中金红石相 $\mathrm{TiO}_{2}$ 的粒径基本稳定, 其百 分含量随制备温度升高而增加. 对于 $\alpha-\mathrm{FeOOH}$, 当制备 温度低于 $60{ }^{\circ} \mathrm{C}$ 时其粒径基本稳定; 高于 $75{ }^{\circ} \mathrm{C}$ 时, 其百分 含量随制备温度的升高显著降低. 由此可见, 金红石相 $\mathrm{TiO}_{2}$ 和 $\alpha-\mathrm{FeOOH}$ 的粒径大小与制备温度有关, 样品中金 红石相 $\mathrm{TiO}_{2}$ 的含量与制备温度呈正相关, 而 $\alpha-\mathrm{FeOOH}$ 的 含量与制备温度呈负相关.

\subsection{TEM结果}

图 2 为各样品的 TEM照片. 由图可见, 载体 $\alpha-\mathrm{FeOOH}$ 呈棒状, 表面光滑, 直径 $200 \mathrm{~nm}$ 左右; $30^{\circ} \mathrm{C}$ 时 它与 $\mathrm{TiCl}_{4}$ 水溶胶反应后, 其表面包覆一些其它物质, 且 包覆厚度不均匀. $45^{\circ} \mathrm{C} 反$ 应后 $\alpha-\mathrm{FeOOH}$ 表面包覆大量 针状金红石相 $\mathrm{TiO}_{2}$ 颗粒, 且形成厚度100 150 nm的完整 致密包覆层; 当反应温度升至 $60{ }^{\circ} \mathrm{C}$ 时, $\alpha-\mathrm{FeOOH}$ 表面包 覆了较多的金红石相 $\mathrm{TiO}_{2}$ 颗粒; 至 $75^{\circ} \mathrm{C}$ 时, 样品的微结 构发生了显著变化, 形成了明显的管状结构, 管内空长 大于 $600 \mathrm{~nm}$, 直径大于 $100 \mathrm{~nm}$, 且随着制备温度的升高 而增大, 管壁具有明显的双层结构, 即结构较为完整的 层状壁及其外侧的颗粒层. 结合高温 $\left(\geqslant 75^{\circ} \mathrm{C}\right)$ 制备样品 的XRD结果可认为, 构成样品管壁的应为金红石相 $\mathrm{TiO}_{2}$. 上述结果表明, 高温时制得的样品为 $\mathrm{TiO}_{2}$ 管. 将管内空 
腔与载体 $\alpha-\mathrm{FeOOH}$ 的形貌和大小对比, 两者的吻合度很 好. 这应是由于高温时, $\alpha-\mathrm{FeOOH}$ 溶解于 $\mathrm{TiCl}_{4}$ 水解所产 生的酸性溶液中所致. 由此说明, 温度对所制样品微结 构的影响很大. 综上可见, 样品形貌、晶相组成和微结构 特征与其制备温度密切相关.

为进一步确认载体 $\alpha-\mathrm{FeOOH}$ 与金红石相 $\mathrm{TiO}_{2}$ 包覆 层之间的关系, 对 $\alpha$-FeOOH和TY-45-2样品进行了高分 辨率透射电镜(HRTEM)及电子衍射的表征, 其中电子衍 射图是由傅里叶变换(FFT)生成的, 结果见图3. 可以看 出, $\alpha-\mathrm{FeOOH}$ 为单晶结构, 晶粒完整, 对应的晶面如图 3(a)标记所示, 其FFT为对称性良好的六边形, 如图3(a) 中嵌入图所示. 图3(b)中a, b 和c处的晶格间距分别为 $0.2188,0.3174$ 和 $0.2472 \mathrm{~nm}$, 分别与金红石相 $\mathrm{TiO}_{2}(111)$, (110)和(101)晶面(JCPDS 21-1276)的间距接近, $d$ 处晶格 间距为 $0.2658 \mathrm{~nm}$, 与 $\alpha-\mathrm{FeOOH}$ (130) 晶面接近. 图3(b)右 下嵌入图为 TY-45-2样品的电子衍射照片, 为典型的同 心圆环多晶衍射. 这说明样品由多晶组成. 图3(b)白色 方框位于金红石相 $\mathrm{TiO}_{2}$ 与 $\alpha-\mathrm{FeOOH}$ 载体的交界处, 右上 角嵌入图是对其的局部放大, 其中的折线为界面位置. 可以看出, $\alpha-\mathrm{FeOOH}(130)$ 面与金红石相 $\mathrm{TiO}_{2}$ 的(111)和 (110)面的晶格条纹相互交叉. 这说明两相结构在准周 期面内形成了良好的共格关系. 这从微观角度证明金红 石相 $\mathrm{TiO}_{2}$ 在 $\alpha-\mathrm{FeOOH}$ 表面形成的包覆层不是简单的物 理吸附, 而是形成了键合作用.

这是由于 $\mathrm{TiCl}_{4}$ 水解过程中会形成带羟基的中间产 物 $\mathrm{Ti}(\mathrm{OH})_{x}(x \leqslant 4)$, 它与 $\alpha-\mathrm{FeOOH}$ 的羟基发生脱水缩合, 导致两者间形成Ti-O-Fe, 它位于两相界面处, 并产生电 子阱, 即阳离子缺陷. 这可能也是 $30^{\circ} \mathrm{C}$ 所制样品中出现 金红石相 $\mathrm{TiO}_{2}$ 的主要原因.

\subsection{EDS结果}

TY-45-2和TY-90-2样品的EDS结果如图4所示. 图4 $A$ 和B为TY-45-2样品的形貌, C, D和E为EDS元素分布 图. 图 $4 \mathrm{a}$ 和b为样品TY-90-2的形貌, c, $d$ 和e为EDS元素 分布图. 从图4 C, D和E中可以看出, 样品 TY-45-2中O元 素分布较均匀, 与样品形貌轮廓的吻合度较高. Ti元素 和 $\mathrm{Fe}$ 元素的密度分布相反: $\mathrm{Ti}$ 元素主要集中在外侧, 内 侧较少, $\mathrm{Fe}$ 元素主要集中在内侧, 外侧较少. 结合XRD 和TEM结果可充分说明, TY-45-2样品中 $\alpha-F e O O H$ 载体 被金红石相 $\mathrm{TiO}_{2}$ 包裹, 并形成了较为完整的复合结构.

另外, TY-90-2样品中 O, Ti和Fe的元素分布形貌较 相似, 只是强度上有所差异. 其中, $\mathrm{O}$ 和 Ti元素分布密度 相对较强, Fe元素分布密度相对较弱. 这些元素分布轮
廓较相似, 这可能是由于, 高温下 $\alpha-\mathrm{FeOOH}$ 在 $\mathrm{TiCl}_{4}$ 水解 产生的酸性溶液中溶解, $\mathrm{Fe}$ 以 $\mathrm{Fe}^{3+}$ 形式进入 $\mathrm{TiO}_{2}$ 的晶格 内所致. 图4a中, 纳米管的内空形貌与载体 $\alpha-\mathrm{FeOOH}$ 相 似, 仅直径略小. 这可间接证明纳米管的空腔是 $\alpha-\mathrm{FeOOH}$ 溶解后的残留.

\subsection{XPS结果}

TY-90-2样品表面的 Ti $2 p$, Fe 2p及O 1s的高分辨扫 描XPS谱及分峰拟合图见图5. 由图5(a)可见, Ti $2 p$ XPS 谱线均为典型的双峰结构, 即由结合能较低的 $\mathrm{Ti} 2 p_{3 / 2}$ 峰 和结合能较高的Ti $2 p_{1 / 2}$ 峰组成. 通过分峰拟合, 均可得 到 2 组对峰. 说明 $\mathrm{Ti}$ 元素存在 2 种化学状态, 即 458.6 和 $464.4 \mathrm{eV}$, 对应于 $\mathrm{TiO}_{2}$ 的结合能 ${ }^{[24,25]}$, 以及 460.1 和 466.0 $\mathrm{eV}$, 对应于 $\mathrm{TiO}_{x}$ 的结合能 ${ }^{[26]}$. 可见 $\mathrm{TiO}_{2}$ 向 $\mathrm{TiO}_{x}$ 转换出现 了低价态 $\mathrm{Ti}$, 这可能与反应过程中 $\mathrm{Ti}-\mathrm{O}-\mathrm{Fe}$ 键的形成与 断裂及 $\mathrm{Ti}^{4+}$ 与 $\mathrm{Fe}^{3+}$ 的热扩散性质有关 ${ }^{[27]}$.

图5(b)是TY-90-2样品的Fe 2p XPS窄扫谱图. 由图 可见, Fe元素只存在1组对峰, 即711.4和725.0 eV, 分别对 应于 Fe $2 p_{3 / 2}$ 和 $\mathrm{Fe} 2 p_{1 / 2}$. 这说明 $\mathrm{Fe}$ 元素只有 1 种化学状态, 即 $\mathrm{Fe}^{3+}$. 从结合能大小看, $\mathrm{Fe}$ 元素对峰的结合能位置并未 发生太多的偏移. 由于 $\mathrm{Ti}$ 与 $\mathrm{Fe}$ 的电负性相差不大, $\mathrm{Ti}-\mathrm{O}-\mathrm{Fe}$ 键的形成并未使 $\mathrm{Fe}$ 原子内层电子因桥氧键的存 在而受到明显的屏蔽作用 ${ }^{[28,29]}$, 因此结合能没有发生太 大的改变.

图5(c)为TY-90-2样品的O 1s分峰拟合图. 由图可见, O元素存在3种化学状态, 其中529.9 eV对应于 $\mathrm{TiO}_{2}$ 的结 合能 ${ }^{[30]}, 531.4 \mathrm{eV}$ 对应于 $\mathrm{OH}$ 的结合能 ${ }^{[31]}, 533.2 \mathrm{eV}$ 的结 合能较大, 可归结为吸附氧 $\left(\mathrm{H}_{2} \mathrm{O}, \mathrm{O}_{2}\right)$ 的结合能 ${ }^{[31]}$. 从峰 面积可以看出, O $1 s$ 主要以晶格氧Ti-O-Ti形式存在. 这 与前文结果一致. 此外, 金红石相 $\mathrm{TiO}_{2}$ 纳米管表面存在 一定量的 $\mathrm{OH}$, 因而有利于提高样品的光催化活性; 物理 吸附氧的存在则从侧面说明了采用水解沉淀法制备的 金红石相 $\mathrm{TiO}_{2}$ 纳米管具有很高的活性和较强的吸附能 力, 从而有利于样品光催化活性的提高 ${ }^{[31,32]}$.

综上可知, 在低温条件下金红石相 $\mathrm{TiO}_{2}$ 与 $\alpha-\mathrm{FeOOH}$ 通过复合的方式可形成良好的包覆结构; 高温时 $\mathrm{TiCl}_{4}$ 水解产生的酸性溶液能将 $\alpha-\mathrm{FeOOH}$ 溶解, 且 $\mathrm{Fe}^{3+}$ 以掺杂 形式进入了金红石相 $\mathrm{TiO}_{2}$ 纳米管的晶格中. 上述结果说 明, 随着制备温度的改变, 样品结构发生变化, 低温 $(\leqslant$ $\left.45^{\circ} \mathrm{C}\right)$ 下为复合结构, 中温 $\left(60^{\circ} \mathrm{C}\right)$ 为复合兼掺杂结构, 较高温 $\left(\geqslant 75^{\circ} \mathrm{C}\right)$ 为掺杂结构.

\subsection{UV-Vis结果}

图6为P25和所制各样品的UV-Vis谱. 由图可知, P25 
在326 nm处出现吸收峰, 但在可见光区几乎没有吸收峰; $\alpha-\mathrm{FeOOH}$ 除了在 $315 \mathrm{~nm}$ 处出现较弱的吸收峰外, 在 440 $\mathrm{nm}$ 处还有个较明显的吸收峰, 其半峰宽较宽, 吸收的范 围较大; TY-30-2, TY-45-2 和 TY-60-2样品分别在 287, 308 和 $300 \mathrm{~nm}$ 处出现吸收峰, 其峰位相对于 P25 和 $\alpha-\mathrm{FeOOH}$ 略有蓝移. 此外, 这 3 个样品分别在 363 452, 362 458和365 446 nm处出现了范围较宽的吸收. 上述 吸收峰相对于 $\alpha-\mathrm{FeOOH}$ 有所红移, 且吸收边带均有拓展, 分别延伸到 727, 823和821 nm左右. TY-75-2和TY-90-2 在 318 和 $310 \mathrm{~nm}$ 处有较强的吸收峰, 吸收边带为 $573 \mathrm{~nm}$ 和515 $\mathrm{nm}$ 左右, 已拓展到了可见光区.

\subsection{TY-2样品光催化降解甲基橙}

图7为各TY-2样品光催化降解甲基橙的反应性能. 由图可知, 纯金红石相 $\mathrm{TiO}_{2}$ 的光催化降解效果较差, 反 应180 min后, 甲基橙仅降解10\%左右. 所制5个样品的 光催化性能依据其光照 $60 \mathrm{~min}$ 后的曲线特征可分为三种 类型: (1)随着光照时间的延长, 降解效果平稳增加, 如 TY-45-2样品; (2)当光照时间介于 60 150 min时, 降解效 果平稳增加, 继续延长光照时间, 降解效果增加明显, 如 TY-30-2和TY-90-2样品; (3)随着光照时间的延长, 降解 效果持续增强, 如和 TY-75-2样品, 其中TY-60-2样品经 180 min光照后对甲基橙的降解率高达 $79.7 \%$.

$\mathrm{TY}-30-2$ 样品为 $\mathrm{TiO}_{2}$ 与 $\alpha-\mathrm{FeOOH}$ 复合物, $\mathrm{TiO}_{2}$ 颗粒 分布于 $\alpha-\mathrm{FeOOH}$ 表面, 且未形成完整的包覆结构(如图 2(b)所示), 因此, 其光催化降解性能较差. TY-45-2样品 为 $\mathrm{TiO}_{2}$ 与 $\alpha-\mathrm{FeOOH}$ 复合物, $\mathrm{TiO}_{2}$ 针状颗粒分布于 $\alpha-\mathrm{FeOOH}$ 表面, 并形成较为完整的核壳结构(如图2(c)所 示), 如前所述, $\mathrm{TiO}_{2}$ 与 $\alpha-\mathrm{FeOOH}$ 复合后, 在两相界面处可 产生电子阱, 即阳离子缺陷. 这种缺陷能有效地阻碍光 生电子-空穴的复合, 从而提高催化剂的光催化反应效 率 ${ }^{[31 ~ 35]}$. 陈金媛等 ${ }^{[36]}$ 发现, 纳米级铁氧化物的表面存在 大量配位不饱和的氧原子, 因此, 在纳米级钛氧化物表 面也可能存在这种情况, 致使两者界面处的 Ti-O-Fe键 结合能较强. 此外, 与 $\alpha-\mathrm{FeOOH}$ 相比, 样品内部存在大量 的位错、面缺陷等(如图3(b)中e处所示), 也可成为样品的 光催化活性位, 因此其光催化降解性能较好.

TY-60-2样品中 $\mathrm{TiO}_{2}$ 颗粒分布于 $\alpha-\mathrm{FeOOH}$ 表面, 且
形成较为完整的核壳结构 (见图2(d)), 铁离子掺杂入金 红石相 $\mathrm{TiO}_{2}$ 晶格内, 因此, TY-60-2样品兼有复合和掺杂 结构的特征, 以及核壳结构复合和掺杂材料的性能. $\mathrm{Fe}^{3+}$ 掺杂进入到 $\mathrm{TiO}_{2}$ 晶体内, 必导致晶格参数发生畸变. 结合能带理论, 晶格中 $\mathrm{Ti}^{4+}$ 的 $t_{2 \mathrm{~g}}$ 轨道与氧离子的 $p-\pi$ 轨道 相互作用形成了 $\pi$ 与 $\pi^{*}$ 能带, $\pi$ 能带为半导体 $\mathrm{TiO}_{2}$ 的价带, $\pi^{*}$ 能带为半导体 $\mathrm{TiO}_{2}$ 的导带. 当低价的 $\mathrm{Fe}^{3+}$ 取代 $\mathrm{TiO}_{2}$ 晶 格中 $\mathrm{Ti}^{4+}$ 时, 在 $\mathrm{TiO}_{2}$ 带隙中形成新的 $d$ 能带. 由于晶格中 $\mathrm{Ti}^{4+}$ 的 $d$ 轨道在 $\pi^{*}$ 能带下方附近, 所以新形成的 $d$ 能带不能 与 $\pi^{*}$ 能带交迭, 故在禁带中形成了许多分离的杂质中间 能级, $\pi^{*}$ 能带与杂质能级交迭, 分离的杂质中间能级将合 并成杂质禁带并与 $\mathrm{TiO}_{2}$ 导带重叠. 这时半导体光生电子 在吸收较低能量时即可发生跃迁, 光响应范围增大, 光催 化活性增强.

上述结果说明, 复合兼掺杂样品的光催化活高, 又可 延长光生空穴与电子的寿命, 提高其光催化效率, 即掺杂 结构与复合结构能够很好地协同. 这是 TY-60-2样品的 吸收边带拓展到可见光, 也是其光催化性能好于其它样 品的原因. 另外, TY-75-2和TY-90-2样品具有管状结构 和铁离子掺杂特征, 其光催化降解性能好于核壳结构复 合样品, 与复合兼掺杂样品相近, 但性能较差, 较好地体 现了其结构特征.

综上所述, 样品光催化降解有机物性能不仅与其晶 相组成有关, 更与其结构相关.

\section{4. 结论}

在水解沉淀法制备 $\mathrm{TiO}_{2} / \alpha-\mathrm{FeOOH}$ 光催化材料的过 程中, 通过控制反应温度可较好地调控其晶相组成和微 结构特征: 低温时可制得以金红石相 $\mathrm{TiO}_{2}$ 为壳, $\alpha-\mathrm{FeOOH}$ 为核的核壳结构复合材料; 较高温时则得到 $\mathrm{Fe}^{3+}$ 掺杂金红石相 $\mathrm{TiO}_{2}$ 管; 中温时所得光催化材料具有 复合和掺杂两种结构特征. 将金红石相 $\mathrm{TiO}_{2}$ 与 $\alpha-\mathrm{FeOOH}$ 复合, 能明显提升样品的光学性能, $\mathrm{Fe}^{3+}$ 掺杂金红石相 $\mathrm{TiO}_{2}$ 纳米管的吸收边带可拓展到可见光区. 在上述三种 结构的样品中, 光催化降解有机物性能较差的是复合结 构样品, 最好的是复合兼掺杂结构样品, 即样品光催化 性能与结构密切相关. 